\title{
ASSESSMENT OF RIVERBANK FILTRATION FOR POTABLE WATER SUPPLY IN UPPER EGYPT
}

\author{
Mohamed Shamrukh \\ Associate Professor, Department of Civil Engineering, Faculty of \\ Engineering, Minia University, Minia, Egypt. \\ e-mail: mshamrukh@hotmail.com
}

(Received March 11, 2006. Accepted June 24, 2006)

\begin{abstract}
Riverbank filtration $(R B F)$ is a process in which river water is induced to flow through riverbed soils to pumping wells located on the banks. During this passage through the riverbed and aquifer, dissolved and suspended contaminants as well as pathogens are removed. In Upper Egypt, there is interesting in implementation of RBF because it has the potential to replace the current bad quality groundwater wells. In this study, a pilot studied site consisting of three handpumps installed about $8 \mathrm{~m}$ from a main canal was monitored. These handpumps are used to supply potable water for private houses, Qena Governorate, Upper Egypt. Water samples from these handpumps, main canal, and municipal groundwater wells were examined. Quality measurements were carried out. The results of these bank handpumps were compared with those of canal and municipal groundwater wells. Phiso-chemical quality of handpumps water is acceptable for drinking. There is a caution about the microbial quality of produced water. The cost of applying RBF technique is less than traditional surface water or groundwater treatment plant. Results of this pilot-scale site showed the effectiveness of RBF as a suitable method in Upper Egypt with low cost.
\end{abstract}

KEYWORDS: Water supply, Riverbank filtration, River Nile, Water quality

\section{INTRODUCTION}

The concept of RBF began in 1870's in Germany, and it is a common water production technology in Europe. In the industrial regions of Europe, RBF is used as a pre-treatment technology preceding more advanced treatment operations. In the United States, RBF systems have been operating for about half a century, and often provide the only treatment other than chlorination and fluoridation prior to consumption. According to a conservative estimate, potential exists for 67 million people to be served by riverbank filtration in the USA [1]. Increasing concern regarding the impact of surface water contamination is driving many utilities to seek a higher quality of source water, and many are investigating riverbank filtration. 
Riverbank filtration is a process in which pumping wells located along riverbanks induce a portion of the river water to flow toward the wells (Figure 1). Groundwater wells located adjacent to a body of surface water (river, lake) may, over time, withdraw enough water from the flow system to reverse flow gradients and induce water from the surface source. Wells are commonly placed in close proximity to riverbanks and lakes to take advantage of this induced infiltration thereby maximizing the water-supply potential of the area. Because it is a natural process, bank filtration wins support from consumers who want safe, but not highly treated, drinking water supplies. Bank filtration is an inexpensive and natural method for raw water treatment.

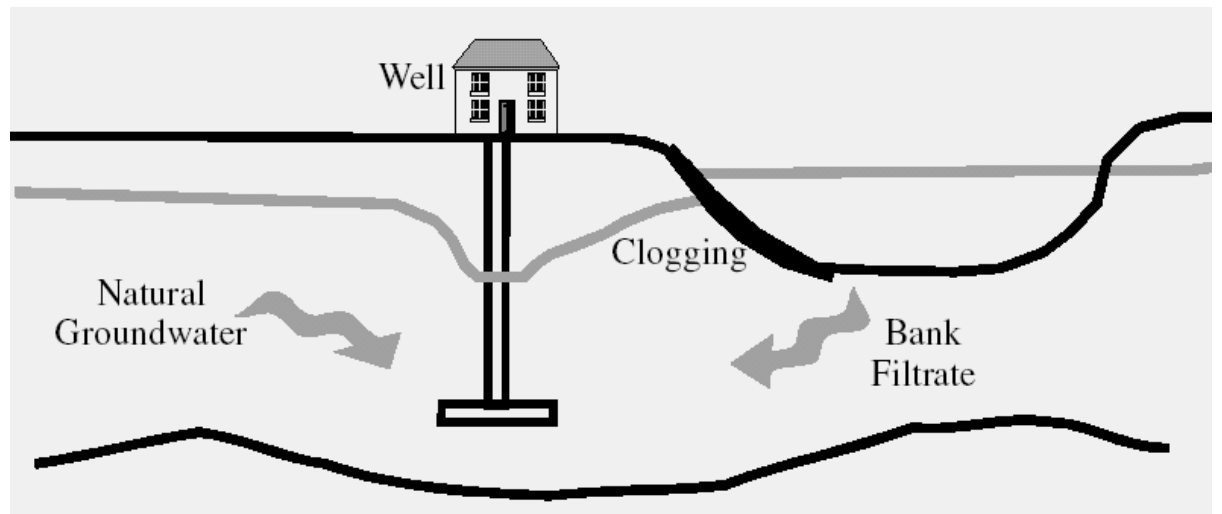

Figure 1. Schematic diagram of riverbank filtration.

Bank filtration is so effective in treating river water and offers so many additional benefits that it can replace or support treatment steps in a water plant. It is possible that bank filtrate can be used as a potable water source without requiring any further treatment. According to Kuehn and Mueller [1], the quality of the surface water is the main factor in determining whether bank filtration will be an adequate drinking water treatment process. During RBF, which has many similarities to slow-sand filtration, river water contaminants are attenuated from a combination of processes such as filtration, microbial degradation, sorption to sediments and aquifer sand, and dilution with background groundwater [2]. Many substances present in surface water, such as natural organic matter or biodegradable micropollutants, are largely removed by RBF. Furthermore, bank filtration is able to provide protection against shock loads.

The main objective of this research is to determine whether RBF is effective at removing particulates and microbial pathogens in Nile valley aquifer for water supply and to replace the current bad quality groundwater wells [3] and [4]. Up to authors' knowledge, no other studies of bank filtration have been performed in Upper Egypt.

\section{MAIN PROCESSES DURING RBF}

As water infiltrates through the riverbank into the aquifer, it experiences chemical changes described by four general types of reactions: electron transfer, weathering, ion 
exchange, and gas exchange. In numerous studies, the most significant chemical changes were related to microbial activity, such as degradation of organic matter or organic pollutants, and were found to occur in the early stages of infiltration [5] and [6]. During RBF, organic solids in the river water are strained out into alluvial sediments. When this intense microbial activity in the riverbed sediments consumes more oxygen than is supplied by the infiltrating river water, an "anaerobic zone" develops. Oxygen becomes significantly depleted in the bed sediments after only a few meters of filtration, in which heavy metals are mobilized. Under these anoxic conditions, the microbial activity of denitrifying and sulfate-reducing bacteria further decreases the redox potential of the system. The resulting highly reduced environment usually affects the stability of mineral surface coatings, such as ferric and manganese oxyhydroxides, that often play an important role in the natural filtration of microbial pathogens. In addition, mobilized manganese and iron can lead to a significant deterioration of water quality. Thus, although the riverbed sediments may act as an effective filter medium in removing various water contaminants, the development of the reduced zone can be detrimental to the quality of bank filtrate.

At a certain distance from the river's side, where microbial activity diminishes as a result of a deficiency in electron donors and the aquifer is re-aerated, the reducing conditions decrease in intensity. Manganese and iron can then be removed from solution by a series of precipitation reactions. Hence, the breadth of the reduced zone can be determined by considering the evolution of manganese and iron along the infiltration flow path. The location of this zone, however, may exhibit spatial and temporal variability due to seasonal fluctuations in microbial activity and water pumping patterns in the well field.

The performance of RBF systems depends upon well type and pumping rate, travel time of surface water into wells, source water quality, site hydrogeological conditions, biogeochemical reactions in sediments and aquifer, and quality of background groundwater [5]. In RBF, underground passage can remove particles, bacteria, viruses, parasites, micropollutants (such as chelating agents, pesticides, amines, pharmaceuticals, sulphonates, and endocrine disrupters), and organic and inorganic compounds [7]. It has also been shown to remove heavy metals, such as chromium and arsenic, by 90\% (Sontheimer, 1980). Enteric viruses and protozoa, such as Cryptosporidium and Giardia, are considered critical waterborne pathogens for drinking water protection. RBF Removal of microorganisms consists of inactivation and adsorption to soil grains, and is primarily dependent on the detention or travel time in the bank, as well temperature, $\mathrm{pH}$, and soil properties. In addition, $\mathrm{RBF}$ filtration has been shown to reduce fragrance compounds, such as major volatile organic carbons and aromatic hydrocarbons by microbial degradation [8].

\section{MATERIALS AND METHODS}

\subsection{Environmental Setting}

In Upper Egypt, there are quality problems of groundwater supply through municipal wells. In order to determine whether RBF will be a beneficial component of the water supply scheme in the Nile portion of Upper Egypt, a pilot study site evaluation is 
required in order to obtain the necessary data. The studied site is located at AbouTishit County, Qena Governorate, along a main canal branching from River Nile (Figure 2). This RBF pilot study site offers important advantages as the researchers can evaluate the first experiment of RBF technique for River Nile in Egypt. For this pilot experiment, a short distance from the main canal to handpumps was designed to minimize the impact of background groundwater on abstraction water.

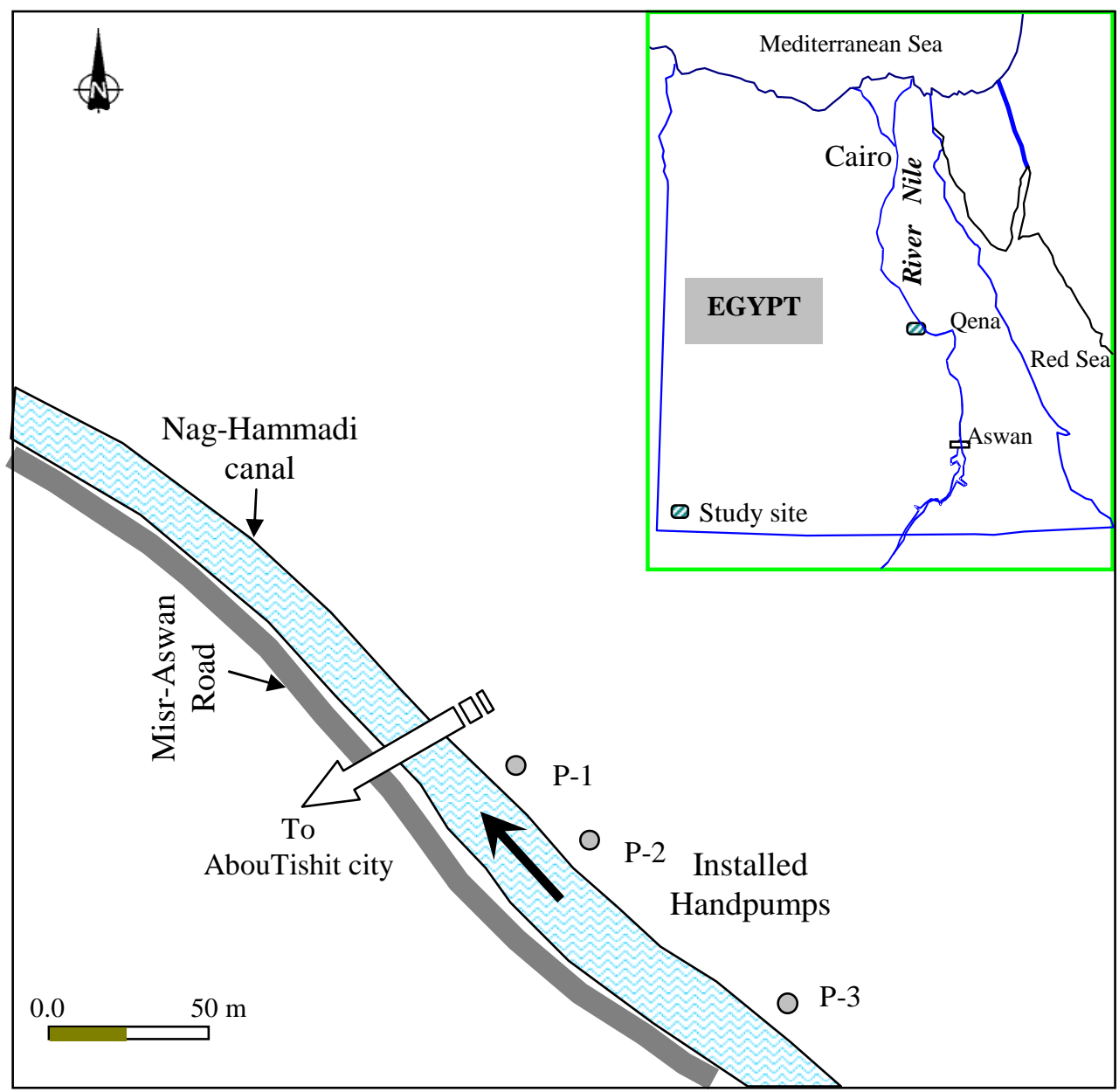

Figure 2. Location of study site AbouTishit County, Qena governorate.

In the studied site, there are three handpumps each equipped with small electrical pump, 1.0 HP. The three handpumps were operated for two months before sampling. Thus, the abstracted water drawdown the groundwater head at handpumps. This drawdown induced water flow from main canal towards the abstraction point. The distance between handpumps and canal bank is about $8 \mathrm{~m}$. The three handpumps are about 15 to $18 \mathrm{~m}$ in depth. The average production volume of each handpump is about $3 \mathrm{~m}^{3} /$ day (i.e. the pump is almost one hour on and the rest of the day is off). 
In Egypt, River Nile has formed a long, narrow valley with varying width from $3 \mathrm{~km}$ at Aswan to about $20 \mathrm{~km}$ at El-Minia [9]. The valley floor formed by the flood-plain of the River Nile is very flat. The entire valley is mainly used for agricultural activities except for those areas occupied by buildings and roads. Nile River aquifer comprises highly permeable sands and is of variable thickness of about $250 \mathrm{~m}$. In most of the valley, the aquifer is overlain by a semi-confining layer, comprising clays and silts. This layer varies in thickness with a maximum generally not exceeding $20 \mathrm{~m}$ [9]. The water transmitting properties of the aquifer are excellent with transmissivity as high as $8000 \mathrm{~m}^{2} /$ day in the central part of the valley. The semi-confining layer overlying the aquifer has an average horizontal and vertical hydraulic conductivity of 30 and $6.0 \mathrm{~mm} /$ day.

Groundwater table is 2 to $3 \mathrm{~m}$ from the ground surface. The regional piezometric head indicates that groundwater movement is generally towards the river Nile, which acts as a major natural drain. The recharge to groundwater is largely derived from irrigation water. Recharge components include the deep percolation of surplus irrigation application and seepage losses from irrigation canals. Recharge from rainfall is generally minor. In urban areas, recharge in the form of leakage from water supply distribution and sewer systems may be significant. The natural discharge is in the form of groundwater flow to the river Nile, in the form of capillary flux to the root zone of irrigated crops, and as drainage outflow to artificial drainage systems. Finally, some discharge is in the form of groundwater abstraction for water supply and irrigation. Generic hydrogeological cross section of the pilot handpumps is illustrated in Figure 3. The most important layer is the biologically active surface layer responsible for much of the effectiveness of RBF systems located at the canal bed.

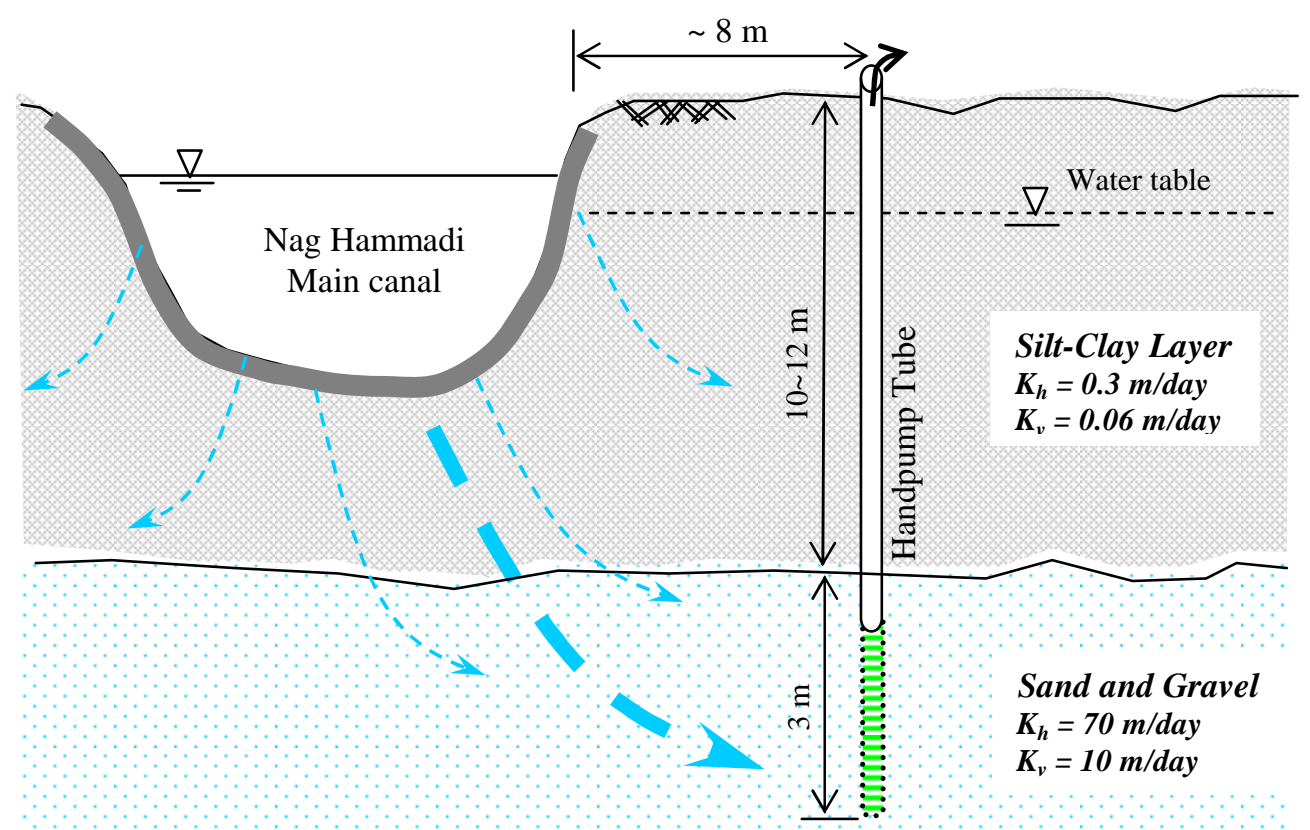

Figure 3. Hydrogeological cross section over the canal bank filtration site. 


\subsection{Sampling And Measurements}

The studied site is located at Upper Egypt. The canal bottom sediments and aquifer materials may be used as a filter process for the recharged water. Because of slow infiltration rates and pore size of the aquifer material, turbidity and pathogen removal can be significant. Water quality monitoring at this pilot handpumps RBF was conducted at the three locations. These three sampling locations are canal water as induced surface water, background groundwater, and discharging water from the handpumps. Samples of canal water were collected from the depth of $0.5 \mathrm{~m}$ from surface near the handpumps. Background groundwater is from ten municipal wells. Physio-chemical water quality measurements and microbial parameters were analyzed during the monitoring period. Typical surface water parameters of concern include: pathogens, nitrite, phosphate, sulfate, iron, manganese, turbidity, TDS, and $\mathrm{pH}$. Particles measured as turbidity is a typical general water quality parameter for most surface waters and is a useful measurement tool for water quality analyses. Collected samples were analyzed using a Hach DR2000 Spectrophotometer for physio-chemical measurements [10]. Other meters for $\mathrm{pH}$ and TDS measurements were used. Instrument startup and analysis were carried out as detailed in the operating manual and each measurement was made in duplicate. Microbial measurements for pathogens were carried out using PathoScreen medium from Hach Company detect fecal contamination [11]. Hach's PathoScreen medium can detect hydrogen sulfideproducing organisms proven to be associated with fecal contamination. Presence and absence method was used. The measurements of handpumps water were compared with those of the canal water, and the effectiveness of the RBF process is evaluated based on this comparison.

\section{RESULTS AND DISCUSSION}

\subsection{Water Quality}

For this pilot-scale RBF site, three sampling locations were carried out. They are canal as induced surface water, background groundwater, and discharging water from the three handpumps. Important water quality parameters of the three locations at the study site are listed in Table 1. Quality characteristics of the canal (i.e. Nile) water, background groundwater, and abstraction water are different (Table 1). Looking to Table 1, quality parameters of canal water are under the allowable standards for drinking purposes except turbidity and pathogens [12]. In addition, there are very small amounts of dissolved iron, and moderate amounts of manganese.

For abstraction handpumps, all the measured quality parameters are under the allowable limits for drinking purposes according to WHO or Egyptian standards. The only exception is for pathogen which some times give positive results, presence. Table 1 shows that, the handpumps water is a mixture of canal water and background groundwater. In general, there are many chemical and biogeochemical transformations during canal flow path to bank handpumps. For natural background groundwater, there are problems regarding manganese (Mn), hardness and pathogens. There are elevated concentrations for nutrients such as nitrate due to infiltration of irrigation water into groundwater in Nile valley. These previous groundwater quality problems are spread widely in Nile valley aquifer [4]. 
Table 1. General quality parameters at the study RBF site, AbouTishit County.

\begin{tabular}{|l|c|c|c|}
\hline Parameter (mg/l or mention) & $\begin{array}{c}\text { Location (1) } \\
\text { Canal water }\end{array}$ & $\begin{array}{c}\text { Location (2) } \\
\text { Handpumps }\end{array}$ & $\begin{array}{c}\text { Location (3) } \\
\text { Groundwater }\end{array}$ \\
\hline $\mathrm{pH}$ & 7.7 & 7.6 & 7.6 \\
\hline $\mathrm{Fe}$ & $0.06-0.08$ & $0.07-0.10$ & $0.1-0.6$ \\
\hline $\mathrm{Mn}$ & $0.02-0.06$ & $0.04-0.08$ & $0.06-0.4$ \\
\hline $\mathrm{NO}_{3}$ & $0.5-1.3$ & 1.02 .0 & $10-24$ \\
\hline $\mathrm{PO}_{4}$ & $0.5-1.2$ & $0.2-0.4$ & $0.5-1.0$ \\
\hline $\mathrm{SO}_{4}$ & $20-30$ & $35-50$ & $55-75$ \\
\hline $\mathrm{TDS}_{\text {Turbidity }(\mathrm{NTU})}$ & $120-140$ & $130-150$ & $450-620$ \\
\hline Hardness as CaCO & $5.0-8.0$ & $0.3-0.8$ & $0.1-0.4$ \\
\hline PathoScreen & $120-130$ & $180-190$ & $200-235$ \\
\hline & presence & $\begin{array}{c}\text { presence/ } \\
\text { absence }\end{array}$ & $\begin{array}{c}\text { presence/ } \\
\text { absence }\end{array}$ \\
\hline
\end{tabular}

Figure 4 shows the comparison of quality parameters between canal water, handpumps water, and background groundwater. Figure 4 indicates that infiltrating canal water play the key rule to dilute the background groundwater moving into abstraction handpumps. Previous works on RBF technique have proved that it has many similarities with slow sand filtration processes [5]. As example, turbidity in production water has been reduced by about $85 \%$ (Figure 4). Similar to turbidity removal, TDS, and pathogens were also effectively reduced through the RBF process. However, the background groundwater in the study RBF plant has elevated values of some chemical constituents. Therefore, the role of treatment processes for chemicals removal in this RBF site is not clear. Previous works have showed that there are significant reductions in river impurities by RBF in many countries [13, 14, and 2]. Inducing of background groundwater with elevated values of these chemical species into bank wells maybe balance or alter reduction through biochemical reactions of bank filtration. From current measurements, induced Nile water has the main impact on this RBF. Nile filtered water has diluted the natural background groundwater. This dilution led to significant quality improvements of production water.

Another aspect of water quality is the microbiology dimension. However, pathogens such bacteria and viruses of surface canal water were effectively reduced in the RBF handpumps. But some sampled water showed that there are positive results which mean the presence of pathogens in produced RBF water. This microbiology disadvantage maybe due to small retention time due to high travel time of the studied RBF system. The RBF handpumps need to dug far away or deeper to avoid the pathogens contaminations.

\subsection{Capital And Operation Costs}

Capital and operating costs are another conventional evaluation criterion. For the evaluation of alternative technologies, it is proposed that "costs" be assessed as the 
sum of capital and operating. Table 2 shows the main components of capital and operation costs of suggested RBF system for AbouTishit city (10 thousands capita) with comparison to the current situation. The current situation is either using deep municipal wells with iron and manganese treatment unit or using the Compact Unit to treat surface canal water. From Table 2, it is clear that the total cost of suggested RBF system in Nile Valley aquifer, Egypt is lower than the current two methods. However, the quality of produced water from the RBF system in Nile aquifer is acceptable for drinking with no other treatments. Using RBF technique will overcome the quality problems of current using of municipal wells for water supply in rural areas in Egypt with the same or lower cost

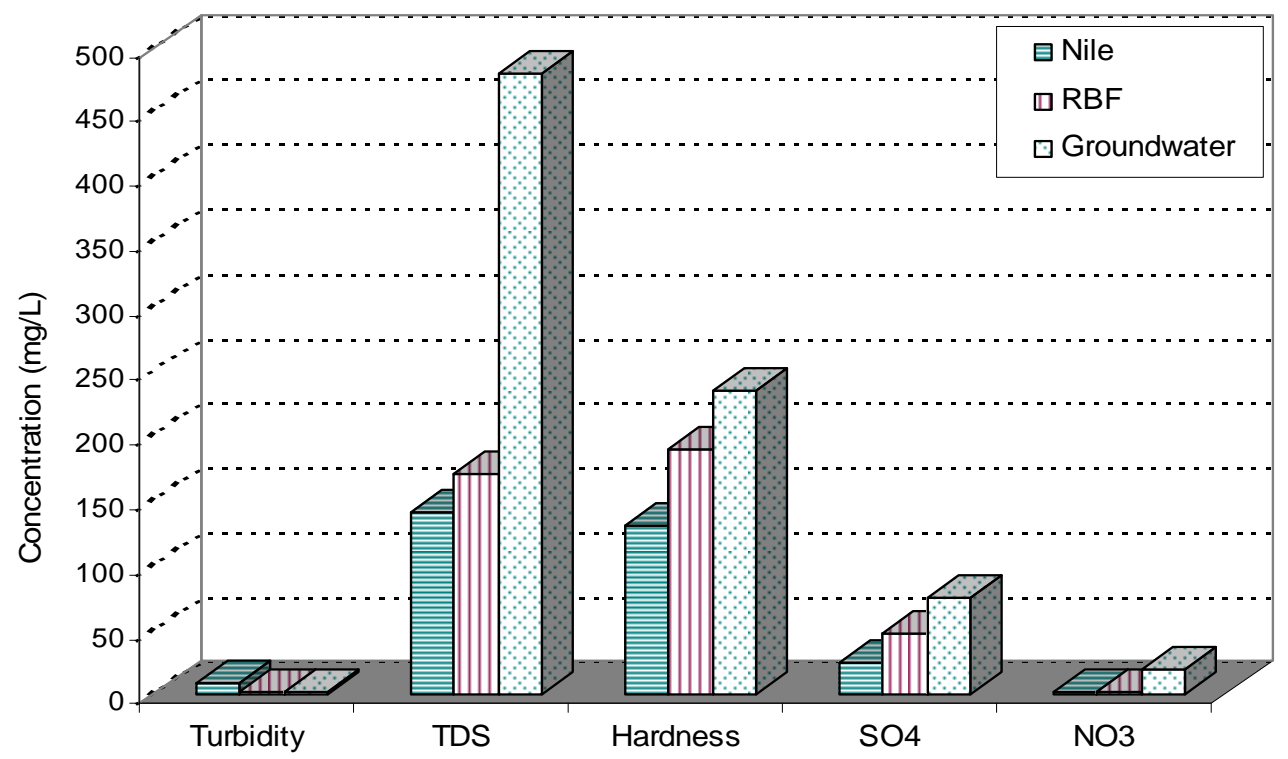

Figure 4. Comparison of Nile, Groundwater, and RBF system.

Table 2. Comparison of capital and operation costs for Compact Unit, municipal wells, and RBF methods.

\begin{tabular}{|c|c|c|c|c|c|c|}
\hline \multirow{2}{*}{ Method } & \multicolumn{2}{|c|}{ Capital Cost } & \multicolumn{3}{c|}{ Operation Cost } & Total \\
\cline { 2 - 7 } & $\begin{array}{c}\text { No. of } \\
\text { pumps }\end{array}$ & $\begin{array}{c}\text { Treatment } \\
\text { units }\end{array}$ & $\begin{array}{c}\text { Power } \\
\text { supply }\end{array}$ & Coagulant & disinfection & cost \\
\hline $\begin{array}{c}\text { Compact } \\
\text { Unit }\end{array}$ & 4 & full units & $\begin{array}{c}2 \text { low pumps } \\
\text { 2 high pumps }\end{array}$ & Needed & needed & $\begin{array}{c}\text { High } \\
\text { cost }\end{array}$ \\
\hline $\begin{array}{c}\text { Municipal } \\
\text { wells }\end{array}$ & $2+$ wells & $\begin{array}{c}\text { iron and } \\
\text { manganese }\end{array}$ & 2 high pumps & No & $\begin{array}{c}\text { May be } \\
\text { needed }\end{array}$ & $\begin{array}{c}\text { Medium } \\
\text { cost }\end{array}$ \\
\hline $\begin{array}{c}\text { RBF } \\
\text { technique }\end{array}$ & $2+$ wells & No & 2 high pumps & No & $\begin{array}{c}\text { May bbe } \\
\text { needed }\end{array}$ & Low cost \\
\hline
\end{tabular}




\section{CONCLUSION}

A first attempt to evaluate the implementation of Riverbank Filtration (RBF) technique in Egypt was carried out. A pilot-scale RBF site is located at Upper Egypt, AbouTishit city, was monitored. Chemical and microbial measurements have proven the effectiveness of RBF system in Egypt. Monitoring values of turbidity, hardness, nitrate, sulfate, iron, manganese, and TDS were significantly reduced to be under the allowable limits. For microorganisms, the efficiency of RBF for pathogens removal needs more research work. In Upper Egypt, RBF could replace the municipal wells which have bad quality water. The capital and operation cost of this RBF system comparing to conventional Compact Unit and municipal wells is lower. These advantages of RBF in Egypt Nile valley make it as proven method for water supply without requiring any further treatment (maybe disinfection) or as pre-treatment for high water quality. Further work is needed to delineate the guidelines for design considerations such as distance from bank and the pumping rate.

\section{REFERENCES}

[1] Kuehn, W. and Mueller, U., "Riverbank Filtration. An Overview", Journal of the American Water Works Association, Vo. 92, pp. 60-69, 2000.

[2] Doussan, C., and Poitevin, G., Ledoux, E. and Detay, M., "River bank filtration: modelling of the changes in water chemistry with emphasis on nitrogen species", Journal of Contaminant Hydrology, Vol. 25, pp.129-156, 1997.

[3] Abdel-Lah, A., Shamrukh, M. and Shehata, A., "Efficiency of Iron and Manganese Removal from Groundwater Using Aeration Tower in Nile Valley, Egypt", $3^{\text {rd }}$ International Symposium on Environmental Hydrology, American Society of Civil Engineers-Egypt Section (ASCE-EGS), Cairo, Egypt, 7 pages (CD proceedings), 2002.

[4] Shamrukh, M. and Abdel-Lah, A., "Monitoring of Agricultural Nutrients in Water Supply Wells, Upper Egypt", Journal of Engineering and Applied Science, Vol. 51(6), pp. 1135-1150, Cairo University, 2004.

[5] Ray, C., "Riverbank filtration: An Analysis of Parameters for Optimal Performance", AWWA annual conference, CD Proceedings, 2001.

[6] Donald, D. and Grygaski, T., "Development of a Sustainable Potable Water Supply for Rural Villages in the Coastal Region of Tanzania, Africa", ENVE 431 Final Project Report, University of Waterloo, Ontario, Canada, 2002.

[7] Brauch, H.J. and Kuhn, W., "Behavior of organic micropollutants during river bank filtration and drinking water treatment", CEE Water Pollution Research Report, EUR 11094, 1986

[8] Jüttner, F., "Efficacy of bank filtration for the removal of fragrance compounds and aromatic hydrocarbons", Water Science Technology, Vol. 40(6), pp. 123128, 1999.

[9] Research Institute for Groundwater (RIGW). "Hydrogeological Map of Egypt: Nag-Hammadi Region (1:100,000)", Water Research Center, Ministry of Public Works and Water Resources, Egypt, 1991.

[10] Hach Company, "DR-2000 Users Manual", Hach Company, Ohio, 1996.

[11] Hach Catalog, Products for Analysis, Hach Company, CO, USA, 1999 
[12] World Health Organization, "Guidelines for drinking-water quality", $2^{\text {nd }}$ Edition, Volume 1, Recommendations, 2005

[13] Irmscher, R. and Teermann, I., "Riverbank filtration for drinking water supply - a proven method, perfect to face today's challenges", Water Science and Technology: Water Supply Vol. 2 (5-6), pp. 1-8, 2002.

[14] Sontheimer, H., "Experience with riverbank filtration along the Rhine River", Journal of the AWWA, pp. 386-390, 1980.

\section{تقييم استخدام طريقة الترشيح عبر ضفة التهر للإمداد بالمياه في صعيد مصر}

الترشيح عبر ضفة النهر طريقة يتم فيها سحب مياه النهر للمرور عبر تربة الضفة إلي حيث أبار

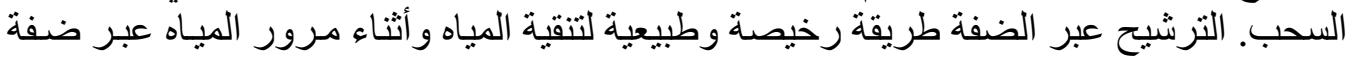

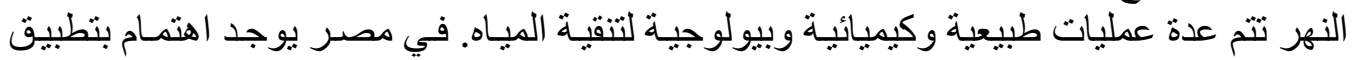

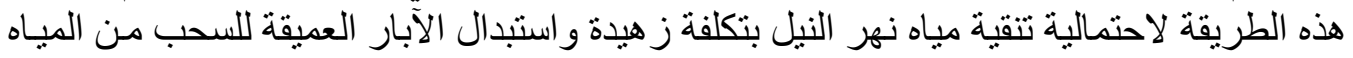

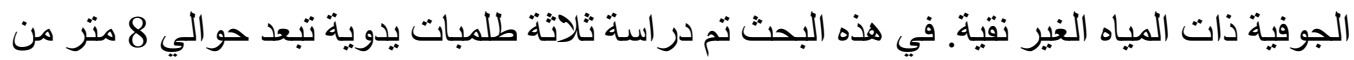

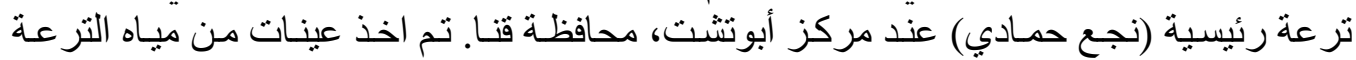

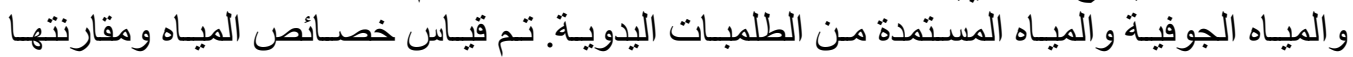

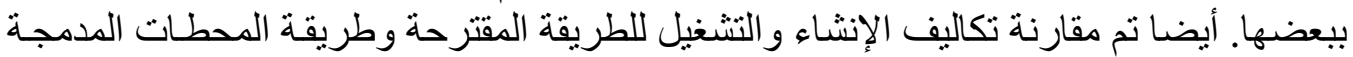

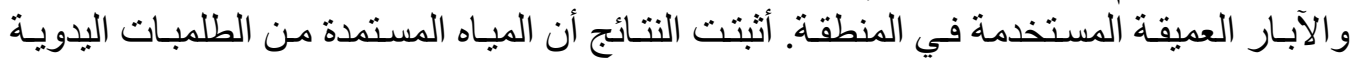

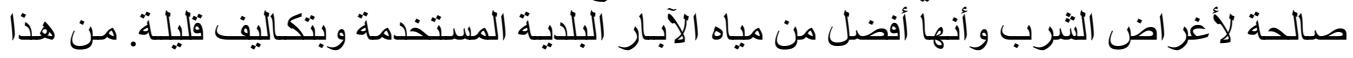

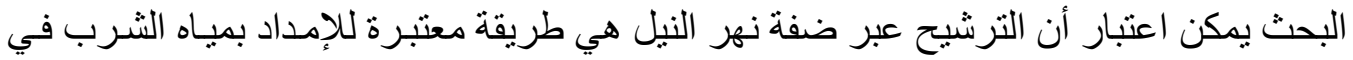

